\title{
Occurrence of Leishmania (Leishmania) chagasi in a domestic cat (Felis catus) in Andradina, Sáo Paulo, Brazil: case report
}

\author{
Ocorrência de Leishmania (Leishmania) chagasi em gato doméstico (Felis catus) \\ em Andradina, São Paulo, Brasil: relato de caso
}

Willian Marinho Dourado Coelho ${ }^{1}$; Valéria Marçal Felix de Lima²; Alessandro Francisco Talamini do Amarante ${ }^{3}$; Helio Langoni4*; Virgínia Bodelāo Richini Pereira ${ }^{4}$; Aziz Abdelnour ${ }^{5}$ Katia Denise Saraiva Bresciani ${ }^{6}$

\author{
${ }^{1}$ Departamento de Medicina Veterinária Preventiva, Faculdade de Ciências Agrárias e Veterinárias, \\ Universidade Estadual Paulista - UNESP \\ ${ }^{2}$ Departamento de Clínica, Cirurgia e Reprodução Animal, Faculdade de Odontologia, Universidade Estadual Paulista - UNESP \\ ${ }^{3}$ Departamento de Parasitologia, Instituto de Biociências, Universidade Estadual Paulista - UNESP \\ ${ }^{4}$ Departamento de Higiene Veterinária e Saúde Pública, Faculdade de Medicina Veterinária e Zootecnia, \\ Universidade Estadual Paulista - UNESP \\ ${ }^{5}$ Faculdade de Ciências Agrárias e Veterinárias, Fundação Educacional de Andradina - FEA \\ ${ }^{6}$ Departamento de Apoio, Produção e Saúde Animal, Universidade Estadual Paulista - UNESP
}

Received March 16, 2010

Accepted October 6, 2010

\begin{abstract}
This work describes natural infection by Leishmania in a domestic cat where amastigote forms of the parasite were observed in the popliteal lymph node imprint. Positive and negative serological reactions were observed by enzyme-linked immunosorbent assay (ELISA) and indirect immunofluorescence assay (IFA), respectively. Polymerase chain reaction (PCR) revealed that the nucleotide sequence of the sample was identical to Leishmania $(L$.) chagasi. This is the first report of the disease in felines of the city of Andradina, SP, an area considered endemic for canine and human visceral leishmaniasis.
\end{abstract}

Keywords: Cat, Leishmania chagasi, PCR, serology.

\section{Resumo}

Neste trabalho, é relatada a infecção natural por Leishmania em um gato doméstico no qual, formas amastigotas do parasito foram observadas em imprint de linfonodo poplíteo. Reações sorológicas positivas e negativas foram observadas pelo teste de imunoadsorção enzimática (ELISA) e reaçáo de imunofluorescência indireta (RIFI), respectivamente. A reação em cadeia da polimerase (PCR) revelou que a sequência de nucleotídeos foi idêntica à Leishmania $($ L. chagasi. Este é o primeiro relato da doença em felino da cidade de Andradina, Estado de São Paulo, Brasil, área considerada endêmica para leishmaniose visceral canina e humana.

Palavras-chave: Gato, Leishmania chagasi, PCR, sorologia.

\section{Introduction}

The occurrence of visceral leishmaniasis in cats has been described in several countries (MANCIANTI, 2004; MARTÍN-SÁNCHEZ et al., 2007; MAIA et al., 2008; NASEREDDIN et al., 2008), including Brazil (SAVANI et al., 2004; SILVA et al., 2008). Skin lesions have also been reported in cats with leishmaniasis (PENNISI et al., 2004).

\section{${ }^{*}$ Corresponding author: Helio Langoni}

Departamento de Higiene Veterinária e Saúde Pública, Faculdade de Medicina

Veterinária e Zootecnia, Universidade Estadual Paulista - UNESP,

Distrito Rubiāo Jr., s/n CEP 18618-970, Botucatu - SP, Brazil;

e-mail: hlangoni@fmvz.unesp.br
Here we describe a case of natural infection of a domestic cat by Leishmania chagasi in the city of Andradina, located in an area endemic for human and canine visceral leishmaniasis. Andradina is in the region of Araçatuba / Sáo Paulo $\left(20.8961^{\circ}, 51.37944^{\circ}\right)$ at $405 \mathrm{~m}$ of altitude.

This study was approved by the Ethics Committee on Animal Experimentation of the Faculty of Dentistry of Araçatuba - UNESP - Protocol No. 2007-003276.

The feline, a male adult mongrel, was given for euthanasia by his owners to the local Center for Animal Control. This animal was from the urban area and had extensive dermatitis with crusts 
and small ulcers on its face as well as on the palmar and plantar areas of its legs.

Leishmania spp. amastigotes were seen in the feline's lymph node imprints stained with Quick Panoptic kit (Hematocor Biolog ${ }^{\oplus}$ ), but not in imprints from bone marrow, spleen, liver, and skin lesions. Analysis of serum sample was negative by IFA (cut-off 1:40) and positive by ELISA performed as described by Lima et al. (2005) with protein A as an antigen, in triplicate. Serology for feline immunodeficiency virus (FIV) and feline leukemia (FeLV) performed with the kit Snap ${ }^{\circ}$ Combo Plus Test, was negative.

DNA was extracted from lymph nodes and spleen samples using Genomic Prep ${ }^{\mathrm{TM}}$ Cells and Tissue DNA GE Healthcare kit. PCR reactions were performed at final volumes of $25 \mu \mathrm{L}$ containing reaction buffer $(10 \mathrm{mM}$ Tris $\mathrm{HCl}, 50 \mathrm{mM} \mathrm{KCl}), 1.5 \mathrm{mM}$ $\mathrm{MgCl}_{2}, 0.2 \mathrm{mM}$ dNTP, 0.2 units Platinum Taq DNA polymerase (Invitrogen), 10ng of extracted DNA, and $10 \mathrm{mmol}$ of each of the RV1 and RV2 primers (LACHAUD et al., 2002). RV1 primer sequence (5'-CTTTTCTGGTCCCGCGGGTAG-3') and RV2 primer sequence (5'-CCACCTGGCCTATTTTACACCA -3') produce a 145 bp-conserved region present in all Leishmania species. PCR mixtures were incubated in a thermocycler Mastercycler Gradient (Eppendorf) using the following cycling profile: initial denaturation at $94{ }^{\circ} \mathrm{C}$ for 4 minutes, 40 cycles of $94^{\circ} \mathrm{C}$ for 30 seconds, $59^{\circ} \mathrm{C}$ for 30 seconds, $72{ }^{\circ} \mathrm{C}$ for 30 seconds, and $70{ }^{\circ} \mathrm{C}$ for 10 minutes. The amplified products were analyzed by electrophoresis on $1.5 \%$ agarose gel stained with $\mathrm{SYBR}^{\circ}$ safe (Invitrogen ${ }^{\circ}$.

The amplified fragments were visualized with an image analyzer (GelDoc-IT ${ }^{\mathrm{TM}}$ Imaging System), using the software Vision Works ${ }^{\circ}$ LS. Next, amplicons were purified with the enzyme ExoSAP-IT (USB) and sequenced on MegaBace 1000 DNA sequencer (GE Healthcare) using the termination kit DYEnanic ET Dye (GE Healthcare). The sequences were compared with those deposited in the NCBI database using blastn (Basic Local Tool for Nucleotide Alignment). Positive fragments of L. chagasi were detected in tissue samples of spleen and bilateral popliteal lymph nodes (Figure 1). Database alignments of the amplified fragments showed $97 \%$ identity with the DNA sequences of $L$. chagasi in the GenBank: Z35276.

The occurrence of Leishmania in cats has been described by parasitological, molecular (HATAM et al., 2010; TABAR et al., 2008), and serological tests (DIAKOU et al., 2009; SOLANO-GALLEGO et al., 2007) as well as by IFA (MAROLI et al., 2007; AYLLON et al., 2008).

Using parasitological and serological assays, previous studies reported an occurrence of $6.5 \%(13 / 200)$ of animals infected with Leishmania spp., in the municipality of Araçatuba, located at approximately $120 \mathrm{~km}$ from Andradina (ROSSI, 2007). In other countries, epidemiological surveys using IFA and PCR revealed a ratio of 30.4\% (7/23) in Portugal (MAIA et al., 2008), and 6.7\% (7/104) in Israel using ELISA (NASEREDDIN et al., 2008).

Taken together, these studies indicate that cats may play an important role in the epidemiology of leishmaniasis, acting as a possible source of infection (DA SILVA et al., 2010). More detailed studies will be necessary to assess feline's contribution in the maintenance and spread of leishmaniasis in different environmental conditions

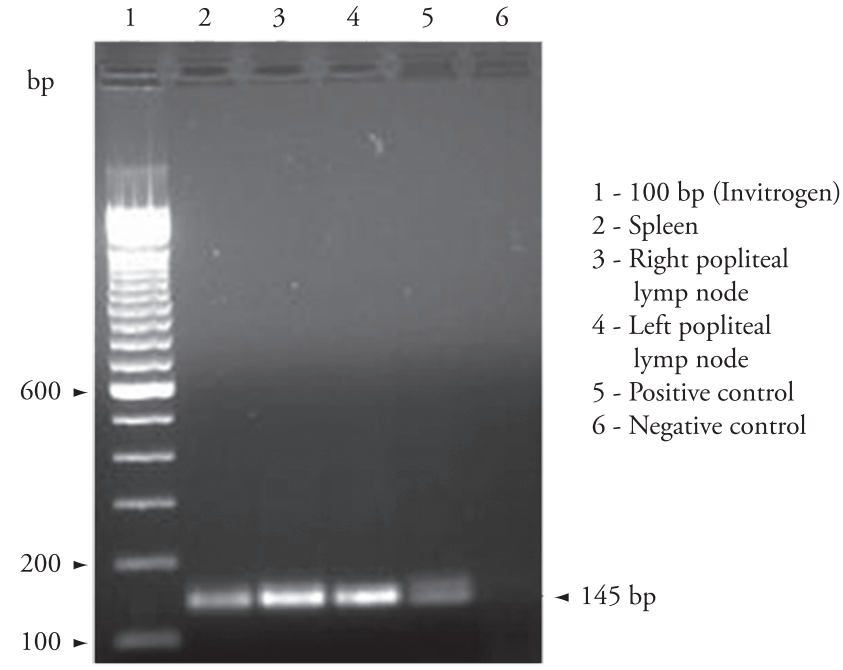

Figure 1. Electrophoresis of the PCR products obtained from cat spleen, and right and left popliteal lymph node samples using RV1 and RV2 primers. PCR products of $145 \mathrm{bp}$ are shown.

According to the data revealed herein it is plausible to think that in an area endemic for canine visceral leishmaniasis, with confirmed reports of human infection, cats may also be affected by the parasite.

\section{References}

AYLLON, T. et al. Serologic and molecular evaluation of Leishmania infantum in cats from central Spain. Annals of the New York Academy of Sciences, v. 1149, p. 361-364, 2008.

DA SILVA, S. M. et al. First report of infection of Lutzomyia longipalpis by Leishmania (Leishmania) infantum from a naturally infected cat of Brazil. Veterinary Parasitology, v. 174, n. 1-2, p. 150-154, 2010.

DIAKOU, A.; PAPADOPOULOS, E.; LAZARIDES, K. Specific anti-Leishmania spp. antibodies in stray cats in Greece. Journal of Feline Medicine and Surgery, v. 11, n. 8, p. 728-730, 2009.

HATAM, G. R. et al. First report of natural infection in cats with Leishmania infantum in Iran. Vector Borne and Zoonotic Diseases, v. 10, n. 3, p. 313-316, 2010.

LACHAUD, L. et al. Comparison of six PCR methods using peripheral blood for detection of canine visceral leishmaniasis. Journal of Clinical Microbiology, v. 40, n. 1, p. 210-215, 2002.

LIMA, V. M. F. et al. Serological diagnosis of visceral leishmaniasis by an enzyme immunoassay using protein $\mathrm{A}$ in naturally infected dogs. Pesquisa Veterinária Brasileira, v. 25, n. 4, p. 215-218, 2005.

MAIA, C.; NUNES, M.; CAMPINO, L. Importance of cats in zoonotic leishmaniasis in Portugal. Vector Borne and Zoonotic Diseases, v. 8, n. 4, p. 555-559, 2008.

MANCIANTI, F. Feline leishmaniasis: what's the epidemiological role of the cat? Parassitologia, v. 46, n. 1-2, p. 203-206, 2004.

MAROLI, M. et al. Infection of sandflies by a cat naturally infected with Leishmania infantum. Veterinary Parasitology, v. 145, n. 3-4, p. 357-360, 2007. 
MARTÍN-SÁNCHEZ, J. et al. Infection by Leishmania infantum in cats: epidemiological study in Spain. Veterinary Parasitology, v. 145, n. 3-4, p. 267-273, 2007.

NASEREDDIN, A.; SALANT, H.; ABDEEN, Z. Feline leishmaniasis in Jerusalem: serological investigation. Veterinary Parasitology, v. 158, n. 4, p. 364-369, 2008.

PENNISI, M. G. et al. Case report of leishmaniasis in four cats. Veterinary Research Communications, v. 28, n. 1, p. 363-366, 2004.

ROSSI, C. N. Ocorrência de Leishmania sp. em gatos do município de Araçatuba - Sáo Paulo - Brasil. 2007. 87 f. Dissertação (Mestrado) Universidade Estadual Paulista, Jaboticabal, 2007.

SAVANI, E. S. M. et al. The first record in the Americas of an autochthonous case of Leishmania (Leishmania) infantum chagasi in a domestic cat (Felix catus) from Cotia County, São Paulo State, Brazil. Veterinary Parasitology, v. 120, n. 3, p. 229-233, 2004.
SILVA, A. V. M. et al.The first Record of American visceral leishmaniasis in domestic cats from Rio de Janeiro, Brazil. Acta Tropica, v. 105, n. 1, p. 92-94, 2008.

SOLANO-GALLEGO, L. et al. Cross-sectional serosurvey of feline leishmaniasis in ecoregions around the Northwestern Mediterranean. American Journal of Tropical Medicine and Hygiene, v. 76, n. 4, p. 676-680, 2007.

TABAR, M. D. et al. Vector-borne infection in cats: Molecular studies in Barcelona area (Spain). Veterinary Parasitology, v. 151, n. 2-4, p. 332-336, 2008. 